Article

\title{
A Conceptual Shift in Studies of Belonging and the Politics of Belonging
}

\author{
Eva Youkhana \\ Interdisciplinary Latin America Centre, University of Bonn, 53113 Bonn, Germany; E-Mail: eyoukhan@uni-bonn.de
}

Submitted: 29 July 2014 | In Revised Form: 10 November 2014 | Accepted: 19 December 2014 |

Published: 8 July 2015

\begin{abstract}
The study of belonging, its underlying notions, and the politics of belonging shows that social, political, and territorial demarcations are still based on essentialist conceptions of the collective. These are often applied and reproduced in the social sciences as a result of methodological nationalism. Space-sensitive studies of migration and globalization and a return to the material have recently challenged social constructivist lines of argumentation and have provoked a conceptual shift from analytical categories with inherent spatiality, territoriality, and boundary marking to concepts based on movement and flow. In this paper the analysis of belonging and the related politics of belonging in migration studies incorporates space as an analytical category that cross-cuts established categorizations such as race, class, gender, and stage in the life cycle, and integrates a material semiotic perspective more systematically into the study of social relations at the intersection of the social categories mentioned. A new concept of belonging is defined which reflects the complex relations that individuals have with other people, circulating objects, artefacts, and changing social, political, and cultural landscapes, thus mirroring both the material conditions and the underlying power relations. Such an understanding of belonging proceeds from social naturalizations and fixations to the multiplicity and situatedness of individual attachments, which entangle social, imagined, and sensual-material relations that are constantly re-articulated and re-negotiated by actors in their day-to-day practices. In such a reading, belonging comes into being as a result of individual life stories, versatile contexts, and situated experiences and acts. In times of constant exchange through travel, mass media, and communication technologies, the conceptualization of belonging questions established sociocultural and political demarcations, indicates the compatibility of ascribed socio-cultural difference and stresses the permeability of borderlines. A space-sensitive theorization of social relations and belonging opens up new perspectives on the question of how social collectives are naturalized and by whom, and under which conditions they open up to new forms of belonging; it thus brings forth new findings about collectivization, social mobilization, and change.
\end{abstract}

\section{Keywords}

belonging; citizenship; creative activism; intersectionality; Madrid; politics of belonging; religious place-making; space; Spain

\section{Issue}

This article is part of a regular issue of Social Inclusion, edited by Professor Ulf R. Hedetoft (University of Copenhagen, Denmark).

(C) 2015 by the author; licensee Cogitatio (Lisbon, Portugal). This article is licensed under a Creative Commons Attribution 4.0 International License (CC BY).

\section{Introduction}

People often resort to notions of belonging that are tied to territoriality, memorizations of landscapes, lifestyles, and cultural imprints, which are even reinforced in the context of migration. Senses of deprivation are stressed and gain particular meaning as the challenges in the country of immigration pressurize the immigrants, endanger their livelihoods, and increase their perceived loss of home. Essentialized ideas about the collective are reproduced that are based on primordiality and origin. Scholars of migration studies continue these "groupist" imaginations by using methods that refer to national and ethnic belongings without inquir- 
ing into context and individual background.

One challenge faced by social scientists and scholars of migration studies lies in the attempt to avoid using naturalized concepts of belonging, which seem to have been overcome in theory but still remain in academic practice due to "methodological nationalism" (Wimmer \& Glick-Schiller, 2006) or essentialism in research designs. A genealogical understanding of belonging, inherent in social sciences and Western binary thinking, risks taking social collectives for granted while uncoupling from the analysis of impact factors such as biographical particularities and institutional power claims (state apparatuses, cf. Althusser, 2010 [1971]), and the influence of concrete socio-political and cultural contexts (Wimmer, 2009, p. 244), even when the analysis is accompanied by reflection from an intersectional or interdependent perspective. Antonsich (2010, p. 645) argues that many scholars of the social sciences, geography and cultural studies assume that belonging is a self-explanatory term that subdivides societies into nations, cultures, classes, ethnicities, and sexualities or that stands at the intersection of them, when it is qualified as multiculturalism or cosmopolitanism (cf. Anthias, 2006; Yuval-Davis, 2011). Taking pre-defined cultural, political, or social groups as obvious "units of analysis" is an established paradigm that emanates from the assumption that the same regularities exist in the social world as in the natural world (Belina, 2013, p. 35 after Abler, Adams, \& Gould, 1971, p. 216), involving clear spatial distances and measurable biophysical processes. This so-called geo-determinism, when applied to the study of social relations and migration, is grounded in a concept that imagines space as a biophysical container. According to that assumption, sociocultural groups are supposed to possess a core character that renders behavioural patterns and conflicts immutable (for critiques see Barth, 1969; Brubaker \& Cooper, 2000; Wimmer, 2009, p. 244f), and this assumption is translated into various and diverse politics of belonging without integrating the manifold practices that produce new forms of belonging. These new forms of belonging are visible and significant, and they describe, besides socio-cultural, ethnic, or racial ascriptions and the related meta-structures (ethnic, national, religious belonging), also situated and changing everyday belongingness.

In order to avoid bounded analytical categories and methodological essentialism in migration studies, it is necessary to draw attention to the creative poetic acts within everyday practices and how they transgress dominant ideologies, political practices, and the politics of social boundary making (Lefebvre, 2006; de Certeau, 1980; Joas, 1994). Concepts at the interface of disciplinary thinking that are sensitive to social and material attachments and socio-spatial production processes need to be integrated more systematically into conceptual thinking. With concepts that also reflect the "me- ta-philosophy of the everyday" in the analysis of social relations, to speak with Lefebvre, the traditional occidental and binary thinking that reduces social action to the dialectic between social thought and social practice can be overcome (Schmid, 2005).

In the present paper a concept and definition of belonging is developed with the aim of revealing sociospatial production processes and integrating a material-semiotic perspective into studies of migration and collectivization. Through an interdisciplinary research perspective, conventional notions of the collective are challenged, with a shift from categories with inherent spatialities, territoriality, and boundary making to concepts based on movement and flow. The starting point for the following conceptual reflection upon belonging is anchored in the colloquial meaning of the term: defined as a "circumstance connected with a person or thing", to belong is "to be appropriate or connected with" (Oxford Dictionary, 1989). In this basic definition, the importance of things, infrastructures, artefacts, and material culture in general for the production of belonging is stressed, as is the constant appropriation and remaking of space. The heterogeneity of actors involved in collective processes indicates the immediacy and situatedness of belonging and unveils its underlying spatial and temporal interdependencies.

Research on which the paper is based was conducted within the "Research Network on Latin America: Ethnicity, Citizenship, Belonging", whose researchers investigated processes of social inclusion and exclusion in Latin American societies via the operationalization of the three key terms ethnicity, citizenship, and belonging. A sub-project dealt with the importance of space by using it as an analytical category for studying social dynamics in migration communities. From the example of (Latin American) migrants in Spain/Madrid, (re)productions and (re)presentations of belonging were studied between the years 2010-2014 against the background of different cultural and political practices.

\section{The Concept of Belonging and the Related Politics of Belonging}

When we examine different social science definitions of belonging, we find that the concept ranges from a personal feeling, the sense of belonging to a certain group, place, or social location, to the understanding of belonging as a resource that can be used to draw social demarcations and establish border regimes, the socalled politics of belonging (Antonsich, 2010; YuvalDavis, 2006, 2011). The politics of belonging is the "arena of contestation" (Yuval-Davis, 2011, p. 18) of people and groups with similar senses of belonging. It is necessary first to describe the established social science definitions of belonging and move on to the politics thereafter. 


\subsection{The Concept of Belonging}

Ethnicity and citizenship, both concepts operationalized by the abovementioned Research Network and used as sub-categories of belonging (cf., Albiez, Castro, Jüssen, Youkhana, 2011), are well known in various disciplines and have long been discussed in social sciences and history (for ethnicity cf., Anderson, 1983; Barth, 1969; Elwert, 1989; Gabbert, 2006; Pedone, 2003; and for citizenship, Conrad \& Kocka, 2001; Isin \& Turner, 2002; Cachón Rodríguez, 2009), but belonging is still a rather new theoretical term. Belonging has often been used interchangeably with the term identity (Antonsich, 2010; Pfaff-Czarnecka, 2011), and has been used as a synonym of, or in association with, citizenship, which is agreed to be an entitlement describing a contractual relationship between a person and the state (Antonsich, 2010, Yuval-Davis, 2011, p. 47). Belonging has recently been conceptualized in studies of migration, in sociology, and in anthropology (Anthias, 2006, 2009; Bogner \& Rosenthal, 2009; Christensen, 2009; Pfaff-Czarnecka, 2011; Savage, Bagnall, \& Longhurst, 2005; Social Issues Research Centre [SIRC], 2007; Yuval-Davis, 2006, 2011) in order to better understand political contestations and their ethnic (Büschges \& Pfaff-Czarnecka, 2007; Ströbele-Gregor, 2010; Yashar, 2005; for Africa see Lentz, 2006) $)^{1}$ and religious legitimizations (Castells, 2002 [1997]; Haynes, 2009). With respect to migration studies, where belonging is increasingly contested between and among "host" and "guest" communities, Yuval-Davis (2006) and Anthias $(2006,2008)$ have made important contributions to the theorization of belonging. According to Yuval-Davis (2006, p. 199f), belonging is about a) different social locations that emerge along different power axes and social categorizations, b) individuals' identifications and emotional attachments, and c) shared ethical and political value systems. Using an intersectional approach, belonging is defined as a dynamic process, constructed and negotiated along multiple axes of difference, such as class, race, gender, stage in life cycle, sexuality, and ability (Yuval-Davis, 2006, p. 200). By locating the concept at the interface of different categorizations of the social and their multiple effects of producing unbelonging in the case of inequality and exclusion, the authors introduce an intersectional approach in order to better understand related social contestations. Intersectional approaches were introduced as a theoretical and methodological perspective by feminist theorists in order to include women as the subject of research more systematically and to stress gender as an analytical category (Maj, 2013; McCall, 2005). YuvalDavis justifies the importance of intersectional ap-

\footnotetext{
1 The issue of "first-comers" and "late comers" was discussed by Lentz (2006), who showed how these categories served to control mobility and settlement patterns.
}

proaches by arguing that social locations of belonging are never constructed along a single power axis but refer to different social sections and are therefore multidimensional. To her, "Intersectionality is a metaphorical term, aimed at evoking images of a road intersection, with an intermediate or contested number of intersecting roads, depending on the various users of the terms and how many social divisions are considered in a particular intersectional analysis" (YuvalDavis, 2011, p. 6). The attraction of this is its consideration of multiple narratives of belonging, influenced by different historical trajectories, and of social realities that are able to form senses of belonging far beyond those tied to ancestry, authenticity, and places of origin.

According to Anthias, belonging is situated at the interface between the local and the global, and by that means is able to dissolve the binary semantic of these spatial dimensions. Anthias $(2006,2008)$ introduced the term "translocational positionalities" to contest the inherent spatialities of concepts of belonging and identity, to break with essentialized categorizations of social difference, and to stress the growing complexity of forms of otherness. Here, the spatial reference is twofold and reflects the importance of place-based interaction on the one hand, and movement on the other, or, to speak with Urry $(2000$, p. 133 , after Clifford, 1992), the dialectic of roots and routes. Anthias' term corresponds to the debate on transnational identities and critically reflects upon notions of diaspora, hybridity, and cosmopolitanism by pointing to social relations that are not necessarily linked to bounded and predefined groups. The concept of "translocational positionality" also describes people's positionalities within the complex and shifting life-worlds of an individual (26f). By this interpretation of belonging, Anthias bridges the analytical gap between structure and agency, between different scales and localities, and sensitizes for processes of social exclusion at the intersection of different categorizations. Antonsich (2010, p. $650)$, too, stresses the spatial reference of belonging, which often relates to specific localities and territorialities. Space here can be both a geographic place and a symbolic space described as familiarity, comfort, security, and, to come back to Yuval-Davis' term, an emotional attachment, a feeling of being at home. To Antonsich, belonging is closely linked to a "sense of self" narrated by a personal, intimate, and existential dimension rather than a social resource discursively used to draw boundaries (Antonsich, 2010, p. 647). Senses of belonging used to mobilize collective identities, to create social, cultural, and territorial boundaries, or to allocate citizenship rights is where feelings of placebelongingness translate into "regimes of belonging". The latter term was coined by Pfaff-Czarnecka (2011) to describe the transition from senses of belonging to the politics of belonging by means of creating institutionalized patterns of belonging that are bounded and 
can also be exclusive. In her view these regimes of belonging insist upon investment of time and resources (Pfaff-Czarnecka, 2013, p. 17), and can be both open or closed to newcomers, for example in transnational immigrant societies.

\subsection{The Politics of Belonging}

The politics of belonging are the political arenas related to different notions of belonging, be they ethnic, national, cultural, and/or religious, or cosmopolitan. Migrants relate and resort to different political projects of belonging, which describe relevant contestations and indicate both inclusionary and exclusionary social realities. The most influential political project of belonging remains the nation state, with nationalism forming the ideological ground, and (state) citizenship relating people to national territories (Isin \& Turner, 2007; Yuval Davis, 2011). ${ }^{2}$ Other political projects, such as ethnic and religious communities as well as multinational enterprises, are attributively organized alongside national boundaries even though they operate across them. For this reason the following section concentrates on citizenship and national belonging, and on how national belonging is legitimized and enacted.

\subsection{Nationalism and the Nation State}

Yuval-Davis (2011) organizes the "national question" of the politics of belonging around three main issues: the nation and the nation state, homelands and the construction of national boundaries, and autochthonic politics. Ernest Gellner, in his influential book on nations and nationalism, has described nationalism as a

"theory of political legitimacy, which requires that ethnic boundaries should not cut across political ones and, in particular, that ethnic boundaries within a given state-a contingency already formally excluded by the principle in its general formulationshould not separate the power holders from the rest". $(1983$, p. 1)

This interpretation links social or ethnic diversity under the banner of a nation and creates a new, but even stronger political demarcation. The nation state is the political project of nationalism and this is where the allocation of citizenship and citizenship rights meets imaginations of national belonging and a "feeling of loyalty" within national boundaries (Yuval-Davis, 2011, p.

\footnotetext{
2 The "right to migrate" or the right of those who migrate is often neglected, despite the fact that, since the work of Hannah Arendt about refugees between the two world wars, it has been a topic of human rights debates and has recently been applied to members of the European Union (ius migrandi).
}

81). ${ }^{3}$ Homelands are described by Yuval-Davis as inscriptions of a physical nature, as the spatial locations on which the boundaries of a nation state are based. Within this political project different ethnic groupings are or can be involved, through a rudimentary commitment to ethnic and / or cultural diversity. However, "conviviality of difference" (Yuval-Davis, 2011, p. 99), does not, in turn, hold true for autochthonic politics, described and analysed by Peter Geschiere in the African and European case. According to him, the notion of autochthony plays a crucial role in the formation of belonging within globalizing structures as "some sort of primordial claim" (Geschiere, 2011, p. 175). In his view, the recent "upsurge of autochthony" and related notions of belonging are rooted in extending neoliberal reforms worldwide (Geschiere, 2011). Thus, development guidelines and the belief that decentralization is a panacea providing improvements in livelihoods are contributing to a re- "invention of tradition", " which he illustrates with two examples: the return to community and chieftancy as an area of political orientation in Africa, and the rise of the New Right in Europe.

However, the politics of belonging, or "the dirty work of boundary maintenance", 5 also includes challenges by political agents in order to gain empowerment and "power of" something, rather than maintaining "power over" people (Yuval-Davis, 2011, p. 20). This can be exemplified though developments in Latin America and the rise of, and political projects by, indigenous rights movement. The pluri-national state, for instance, is a concept that indigenous rights movements in Bolivia and Ecuador used after receiving governmental responsibility, in order to empower indigenous groups and to preserve tenure and access to natural resources. In Europe, the debate reflects the aspirations of the "New Right" to separate the European populations. According to xenophobic parties and movements that have recently arisen on the political right, such as PEGIDA (Patriotische Europäer gegen die Islamisierung des Abendlandes) ${ }^{6}$ in Germany, a "multiethnic society" is naturally unstable and must be avoided in order to sustain the nation and its homeland and to prevent so-called ethnic conflicts. What seems to be a legitimate claim by ethnic minorities in the Latin American context is an instrument of domination by the majority society in the European context. The examples show that the production of (pluri-)national ideologies is based on conceptions of authenticity of an

\footnotetext{
${ }^{3}$ Gilroy (1987, p. 59f) also states that nationhood and state citizenship remain an absolute source of patriotism, common values, shared morality, and related political contestations.

4 Hobsbawm and Ranger's book, "The Invention of Tradition" (1983) developed this concept in order to analyse ritual and symbolism within the nation state.

5 Yuval-Davis (2006, p. 204) after Crowley (1999).

${ }^{6}$ Patriotic Europeans against the Islamization of the Occident.
} 
"imagined community" (Anderson, 1983) that have often been invented and reworked by contemporary elites (Hobsbawm \& Ranger, 1983).

\subsection{Citizenship}

Dominant conceptualizations of citizenship derive from the underlying idea that only the state can confer and define citizenship rights. Contemporary and liberal theoretical thinking about citizenship has mainly been influenced by Marshall (1950) and his famous triad of civil, political, and social rights alongside responsibilities, which the subjects of citizenship, the citizens, hold and are obliged to fulfil. ${ }^{7}$ Brubaker (2009) points to (state) citizenships' internal inclusiveness and external exclusiveness, which is why the rights of migrants are debated in regard to the concept. In the view of this theoretical strand of thinking about citizenship, it is always the state that defines the limits of migrants' rights (Joppke, 2010; cf., Albiez et al., 2011).

Over the past two decades, dominant (state) citizenship ideas have been challenged by post-national, transnational (Ong, 1999), global, or cosmopolitan notions of citizenship (Isin, 2009, p. 369) as well as by (multi)cultural (Kymlicka, 1995) and religious (Levitt, 2004) forms of citizenship. Cultural citizenship, as it is termed by Rosaldo (1989), encompasses the necessity of including differences and diversity in dominant discursive and institutional practices, for example those of a nation state. To give consideration to the de-nationalization of politics and economies, political transformations, and the rise of trans-local social relations, a more open conception of citizenship has recently been receiving increasing attention. In this, citizenship is understood as a practice of empowerment rather than a strategy of domination. It is argued that the politics of citizenship need to acknowledge the different sites, scales, and actors involved (Isin, 2009). In this strand of argumentation citizenship is more about a continuum, rather than a dichotomy of being either included in the political project or excluded (Yuval-Davis, 2011). The multi-layered components of citizenship should be studied by "acts of citizenship", a term coined by Isin (2009) in order to describe political activism in contentious politics (cf., Janoschka \& Sequera, 2011). According to him, the "acts of citizenship" become effective across social and political demarcations in order to build new political landscapes for national and international activism, feminist rights movements (Yuval-Davis, 1997), or urban place making (Lepovsky \& Frazer, 2003; Youkhana, 2014b). Thus, the actors of citizenship are not necessarily those

\footnotetext{
${ }^{7}$ As Isin and Turner summarize, "modern citizenship rights that draw from the nation-state typically include civil (free speech and movement, the rule of law), political (voting, seeking electoral office) and social (welfare, unemployment insurance and health care) rights" (Isin \& Turner, 2002, p. 3).
}

who hold the citizenship or a passport. The various fields of contestation (sites) and scopes of application (scales) of citizenship leave fixed and given boundaries, and instead define citizenship as being formed through contestation and struggles (Isin, 2009, p. 370). Furthermore, new political and social landscapes are closely linked to new media and communication technologies based around networks which, as argued by Castells (1996), are contributing to a fundamental change in (political) culture through the interconnectedness and relationality of different social and political fields.

\section{Including Space as a Social Category in Order to Study Belonging}

The citizenship debate shows that belonging is produced beyond ethnic or national boundaries but is contested on interrelated sites, scales, and networks. The question now is why do these "groupist" and "substantialist" conceptions (Brubaker, 2009, p. 28) of belonging and the related politics of belonging persist? Why do we still link the socio-cultural to spatial / territorial terms (Belina, 2013, p. 35), without giving adequate attention to the complex interdependencies of social relations? A critical approach would enrich social constructivist approaches that ontologically still separate the material from the social, and instead include material conditions in the study of social relations and in the analysis of the strategic and political use of essential and naturalized forms of belonging. In fact, the materiality of belonging, such as the power of symbolic forms (Bourdieu, 1992; Magerski, 2005) and deduced intentionalities (Gell, 1998), ${ }^{8}$ as well as the manifold bio-physical and technological processes (Leitner et al., 2008, p. 158) that regulate and mediate social relations (Pierce, Martin, \& Murphy, 2011, p. 57), are often ignored in studies of migration.

\subsection{Space-Sensitive Approaches}

Drawing on French phenomenology (Merleau-Ponty) and German dialectics (Hegel, Marx, Nietzsche) and integrating a "meta-philosophy of the everyday", Lefebvre makes a distinctive claim for the analysis of social relations and productions. Space is understood neither as an absolute or measurable container, nor as a socially constructed or abstract entity, but as a differential unit that connects material and social elements and moments to the analysis of socio-spatial productions (Schmid, 2005, p. 271f). Lefebvre describes a triadic dialectic of social reality by connecting three corresponding moments of social formation, namely

\footnotetext{
${ }^{8}$ Alfred Gell (1998, p. 13f), in his influential work on "Art and Agency", provides the basis for the investigation of a new scientific field in which objects merge with human beings through the existence of social relations between humans and things, and between humans through things in an art work or artefact.
} 
social thought, social practice, and the poetic and creative act (Schmid, 2005, p. 111, 192). The social is lived, perceived, and conceived in space, while also creating space socially (Lefebvre, 2006, p. 335f). In comparison to the occidental binary focus on the dialectic between social thought and social practice, he argues that creativity, reflective action in a specific situation, is especially important for the study of social processes in cities, where transformation through contradictory social practices are most visible (Lefebvre, 2006). Through this theory of the production of space, the incorporation of material conditions, knowledge, meaning, and their entanglement in everyday practices, Lefebvre (2006, p. 330f; see Schmid, 2005, p. 10) opens up new perspectives for the study of belonging. The concept includes social rationality in practice and cultural implicitness in thought. The balancing relation between thought (abstractions) and practice (given conditions) introduced by Hegel and further developed into historical materialism by Marx uses teleological explanations to understand collective action. In Lefebvre's triadic epistemology, this rationality of dialectics is drawn upon, but is at the same questioned with regard to what is accepted as "given" and "real" belonging. The study of the creative acts, the third aspect of socio-spatial production processes, brings to light the simultaneous performances of heterogeneous actors that reflect power relations in productions of belonging. Creative acts show how social formations and belonging are realized and come into being (see Schmid, 2008, p. 31) in certain situations, and they illustrate belonging as a dynamic rather than fixed social fact, which can also be rooted in choices and experiences rather than in imposed identities, genealogies, and positionalities.

Citing post-structuralist geographers (such as Amin \& Thrift, 2002), Doreen Massey (2005) associates space with dynamism and thus qualities of openness, heterogeneity, and liveliness, rather than translating space into a map with sharp edges and a topography, roads, fields, and villages. Space is seen as a product based on the interlocking of natural, social, political, economic, and cultural bits and pieces that simultaneously interact. With regard to collective culture in urban public spaces, Massey is discussing the production of collectives in contemporary urban life that are produced in situations of "throwntogetherness", which is, in Amin's (2008, p. 11) view, a positive social reflex of people in their relation to space and other (material) bodies within them, such as the urban infrastructure, buildings, streets, etc. This "situated multiplicity" in a confined public space may produce social effects and senses of belonging (Amin, 2008).

\subsection{Space as Cross-Cutting Social Category in Intersectional Approaches}

Although the introduction of space as a social rather than just a geographic category highlights some important issues in the study of social relations and the understanding of an intertwined and interdependent system at the interface of race, ethnicity, class, sexuality, and other categorizations, it also challenges the intersectional approach described above. Nakano-Glenn (2011, p. 6) draws attention to traps connected to the use of intersectional approaches that often rely on given and self-explanatory social categories. She favours an expansion of the study of inequality and social exclusion to "more active and coming-into-being approaches" (Nakano-Glenn, 2011, p. 5) by using terminologies such as assemblages and articulations that have crystallized out of approaches in science and technology studies.

As regards the study of assemblages, Latour (2005) opens up new perspectives on the study of social action by stressing relational and network terms in order to understand social relations. And by introducing objects and their agency to social studies, it is indicated that non-humans are not just the "hapless bearers of symbolic projection" (Latour, 2005, p. 10), but are situatively involved in interactions with humans in order to enact and perform the formation of the collective. The performativity of belonging and of the politics of belonging is also stressed by Antonsich and Yuval Davis. Following the feminist theorist Judith Butler as well as Vikki Bell (1999) and Anne-Marie Fortier (2000), YuvalDavis (2011, p. 15f) states: "Specific repetitive practices, relating to specific social and cultural spaces, which link individual and collective behaviour, are crucial for the construction and reproduction of identity narratives and constructions of attachment". Latour (2005, p. 217) argues that the consideration of attachments should be prior to consideration of actors as objects of research, in order to shed light on the enactments of social formations and how they perform and stabilize (unequal) social and power relations.

Intersectional approaches draw attention to the complex interdependencies of social formations and relations, but do so without integrating space and the multiple and heterogeneous bodies within it. Consequently, the approach is conceptually not well placed to consider also the socio-material relations mentioned above, for instance artefacts, technologies, and urban infrastructures. Therefore, the intersectionality approach needs to go beyond reflection upon the established analytical categories and how they interact, correlate, or multiply processes of social exclusion and inequality. Interdependent reflection needs to add the material background to the analysis, or, as suggested by Lefebvre, to add space as an analytical category in social studies. A space-sensitive approach, and thus a material perspective on the study of social relations and collective action, shows on the one hand how and with which instruments different aspects of belonging such as class (socioeconomic), gender and race (body or corporeal aspects), 
ethnicity, and ethical/political value systems (representative and performative aspects) assemble in certain locations and situations. It unveils the underlying power relations that are reflected in the associations of heterogeneous actors and shows how conceptions and the related politics of belonging are enforced and made durable by ideological state apparatuses. On the other hand, a space-sensitive approach similarly allows for the analysis of instruments that are used to overcome the container function of social formations and institutions (Hamel, Lustiger-Thaler, \& Maheu, 2000) by focusing on socio-spatial production processes that are based on the everyday tactics and poetics (de Certeau, 1980) of people who resist social classifications and allocations. Adding space as a social category can, finally, reveal the entanglements, interfaces, and crosslinks of different regimes of belonging in order to visualize the selfdetermining, creative, and diversifying dynamics behind social ordering and "othering" (cf., Law, 2011, p. 32).

\subsection{A Space-Sensitive Definition of Belonging}

In order to develop distinctive methods for the study of belonging I here move beyond disciplinary approaches which often hamper a more holistic view of processes of collectivization. With regard to the spatial and material perspectives described above, a new definition of the concept of belonging stresses the creativity of collective action in the face of changing daily situations and contexts, including both individual particularities and biographical positionalities as well as the social position within hegemonic structures. Therefore I define belonging as:

a socio-material resource that arises by means of multiple and situated appropriation processes. Belonging describes alterable attachments that can be social, imagined, and sensual-material in nature. The material-semiotic and space-sensitive study of belonging reveals activities that produce belonging on different temporal and spatial platforms and within more or less institutionalized (repeated, performed, etc.) everyday practices, (imposed) rituals, and "regimes of belonging".

The concept of belonging defined here incorporates materiality by paying more attention to the entangled material-semiotic aspects of social reality:

1. The corporeal and the individual experiences that people have because of their physical dispositions (external and self-ascriptions by phenotype), ethnic ascription, their gender, embodied experiences, and internalized biographies including the creative poetic acts and enactments of belonging;

2. Tenure relations and the allocation of resources (implied in production factors, including work, soil, capital, and information and communications, and livelihoods and material conditions in general), and the related political enforcement strategies, technologies, infrastructures, and microphysics (cf., Walters, 2013);

3. Objects / artefacts or material cultural productions, forms, and images, which serve (not just) as bearers of agency and which are techniques of representation and signification that are also used to categorize people socially and to carry forward ideologies of social boundary marking (cf., Althusser, 2010 [1971]; Hall, 1985; Papadopoulus \& Tsianos, 2007).

Thus, belonging comes into being between people and things, and between people and people, through material conditions. A more fluid and less bounded conception of belonging can be imagined as a rhizomatic and chaotic network composed of multiple attachments of heterogeneous actors that are not distinguished ontologically, which is why agency and telos can be assigned to both humans and non-humans (Law, 2011, p. 34). The study of belonging assemblages, or the agencement (collection of agency) in the French terminology of Deleuze and Guattari, brings to light a social reality beyond the social, natural, or conceptual framing and scaling. Such a concept marks a break from a sociology that defines the social as a matter of fact rather than a matter of concern (Latour, 2005). It shows how humans are constantly in the "process of becoming" (cf., Papadopoulos \& Tsianos, 2007) by means of materializations and enactments of the collective that are implied in the process of belonging.

\section{The Space-Sensitive Study of Belonging}

In the framework of the "Research Network on Latin America: Ethnicity, Citizenship, Belonging" the relevance of space for the concept of belonging was studied by looking at different articulations of belonging in specific socio-cultural and socio-political arenas, taking the example of migrants in Madrid. Between 2010 and 2014, research was conducted around spaces of representation, institutions, and events where belonging is repeatedly and situatively performed. ${ }^{9}$ The following descriptions illustrate the study of belonging and the politics of belonging, through the example of religious practices, namely the veneration of a replica of the Vir-

\footnotetext{
${ }^{9}$ A portfolio of approved anthropological, sociological, and geographical methods was used and combined into an interdisciplinary research perspective. The methods ranged from videography, to better analyse the rich semantics of performed belongings, through to interview techniques (expert, biographic, ethnographic interviews and inquiries), and participatory observation.
} 
gin of Cisne in a Catholic congregation, and creative activism through graffiti and urban art, both studied in the neighbourhood of Lavapiés, an immigrant and formerly working class neighbourhood in Madrid. The artefacts presented and the material cultural productions both represent power claims, which are made to bring forward both ideologies of social boundary marking and empowerment through creative poetic acts.

\subsection{Place-Making and the Politics of Belonging with the Virgin of Cisne $e^{10}$}

Religious institutions such as the Catholic Church are gaining in importance again in the wake of the economic crisis in Spain. They act as a reference point and meeting place which keeps the faith community together. Tangible assistance is offered and transnational communication structures and family bonds are sustained. With help of replicas of patron saints imported from Latin America, the Catholic Church serves as a place of remembrance that produces and reproduces senses of belongings that date back to the early colonial era (on the Virgin of Guadalupe compare Favrot Peterson, 1992; Zires, 1994). The social relations of migrants are manifested in a space that symbolizes the power and glory of the former colonial regime and a political project of belonging that started with the proselytization and spiritual, political, and economic domination of the Americas by the Catholic Church.

An art work, the figure of the Virgen del Cisne, is here analysed for its relevance to the production and performativity of belonging in different spaces of representation in the migration of Latin Americans to Spain; the analysis thus deals with power negotiations by means of an artefact that comes into action laden with different intentions. By the import of a replica of the Virgen del Cisne, a religious artefact from Ecuador of colonial origin was activated in Madrid with local as well as national and transregional significance. Attempts by the immigrant "Asociación Virgen del Cisne" to (re)appropriate a religious space, to empower the immigrant community and, at the same time, to use the Virgin to legitimize entrepreneurial activities, draws attention also to the identity politics of the Catholic Church in Spain. The empowerment of the members of the association through organized processions and the appropriation of the Virgen del Cisne, assessed as a strong partner, to speak with Alfred Gell, was an affront to the Catholic Church. The Church and the association contested the interpretative dominance over the figure, and in response to the Latin American immigrants the Catholic Church found it necessary to return to its own history by making powerful religious symbols, imported from Europe and reinterpreted in

10 This section is based on my article recently published in Youkhana (2014b, pp. 149-174).
Latin America, available once more in Spain. The conflict that arose between the Ecuadorian/Latin American community in Madrid and the congregation of San Lorenzo in Lavapiés about control over the symbolically charged artefact indicates the continuity of notions of belonging that were ideologized in Christian terms during the Conquista in order to support and legitimize feudalism and Catholicism. ${ }^{11}$ While the Church is increasingly losing ground in Spain, its intervention into both the religious practices and the politics of migration is all the more important for the attempted reconstitution of its claims to power. ${ }^{12}$ Both parties in the conflict, the association and the Catholic Church, used the figure of the Virgen del Cisne to justify their intentions, to bring together the followers in their own interests, and thus to create emotional and cognitive identifications through the symbolic valorization of religious spaces (place making). These hidden mechanisms of "symbolic power" (Bourdieu, 1992, p. 82) are based on repetitive practices and rituals related to the Virgen del Cisne and the establishment of an object-human relationship through which the worshippers unconsciously internalize the interests of both institutions.

Humans can achieve and legitimize power over other humans through sacralized objects. ${ }^{13}$ This correlation between objects and power is evident in studies of religion in which social institutions are to be legitimized by setting the objects in the reference framework of a holy cosmos (cf., Berger, 1973, p. 33). In the case of the Virgen del Cisne power was produced and maintained by means of symbolic acts, rites, and processions (Bell, 1997, p. 91f) backed by art objects and religious artefacts.

\subsection{Creative Activism and Art as Acts of Citizenship ${ }^{14}$}

Creative activism and urban art are increasingly being

11 To this day, the Virgin Mary serves as a link between the Amer-Indian and the European worlds and is thus a product of the trans-Atlantic migration dynamics and transcultural processes. By means of association with their country of origin, she serves as the patron saint for Latin American emigrants (Nabham-Warren, 2006, p. 246). She is, according to García (2005, p. 15), part of an autochthonous collective and territorial identity. The religious locations characterized by her are perceived by believers as islands in an endless sea of foreignness (Jansen \& Keval, 2003, p. 44), a focus for their dreams, wishes, and expectations of the life in the new country.

12 The Marian veneration of Latin American migrants is in addition a social resource for the construction of collective identity, and it is also an instrument with which institutions can improve the integration of immigrants in the host countries (García, 2005; Itçaina, 2006).

13 This deduced intentionality leads Gell to conclude that things also have agency which therefore can strongly influence social relations: "I view art as a system of action intended to change the world" (Gell, 1998, p. 46).

${ }^{14}$ The case study of creative activism was published in Youkhana, E. (2014a, pp. 172-186). 
used as an instrument to collectively re-appropriate the urban space and thus articulate urban belonging and citizenship. In cities worldwide, where different politics of place stimulate capitalist appropriation, the urban space is becoming an arena of international and entrepreneurial competition symbolizing national domination and power. In turn, individuals and groups use the public space as a laboratory for resistance, creative acts and as a medium of communication. As such, creative activism, here exemplified by urban art in Lavapiés, where the politics of place and urban restructuring displace less advantaged people (Youkhana \& Sebaly, 2014), is a manner of articulation for those who are largely excluded from social, political, cultural, and economic participation. Collectives are built through joint action and corporeal experiences that are translated into the production of situated forms of urban belonging. By drawing on space-sensitive and situationist approaches (Debord, 1957) and the power of creativity as an important moment in the analysis of action (Lefebvre, 2006), the example shows how collective action and belonging are produced under conditions of contentious politics and social and territorial exclusion.

Urban art and graffiti are expressions of more general ideas, beliefs, and convictions and are thus subject to conflicts about power over signification and interpretation as well as about access to common urban infrastructures and resources. The urban landscape plays an important role as it serves as an instrument for exercising power by symbolic staging (Heinrich, 2013, p. 7; after Alber, 1997, p. 274). Through the reservation of urban arenas by economic and political institutions and through the creation of a well-structured system of symbols, neoliberal ideologies are conveyed through the public space. Dominant tenure and property rights and the related urban administration necessarily exclude those who are not part of the new entrepreneurialism (Windzio, 2010, p. 93f). Through the interventions of graffiti and urban art that demonstrate and expose this structuring, the artists challenge the power relations represented in the urban forms (Gabbert, 2007 , p. 46). New urban meanings are created by turning the poetics of the art piece into political activism.

However, little attention has been paid to the role of these performances in contentious politics (Waldner \& Dobratz, 2013, p. 377) and as a representation mechanism for protest movements against urban regeneration and revanchism (cf., Youkhana \& Sebaly, 2014). The latest protest movements worldwide have shown that art performances help the producers to escape from voicelessness, to denounce social exclusion and their lack of rights and access to common resources (Abaza, 2013; Waldner \& Dobratz, 2013, p. 381f; after Hanauer, 2011). Graffiti and urban art, since the emergence of New York graffiti, have been used as instruments for protest and a means to produce new forms of (urban) belonging and enact citizenship by those who are ignored by the polity (Baudrillard, 1978; López, 1998). Madrid is a case in point: a global city that exemplifies the new urban geography and politics of territorial and social exclusion. ${ }^{15} \mathrm{~A}$ key factor in the reconfiguration of the city is the transformation of the historic city center, which plays a significant role in the urban dynamics of Madrid. The urban renaissance includes rehabilitation projects, and redesign and control of communal locations, and has led to changes in social tenancy, as well as gentrification and displacement of less advantaged people such as immigrant groups in so-called distressed neighborhoods (Blasius \& Friedrichs, 2008; Youkhana \& Sebaly, 2014). In Lavapiés, a working class and immigrant neighborhood in Madrid, various demonstrations of political urban art are questioning the codes of property rights and belonging by raising sensitivity to the exclusionary character of society (Abarca Sanchís, 2015). The following examples are just a selection of countless art performances in the neighborhood of Lavapíes that represent the practice of urban art as political protest. It can be shown that the art performances are attached to the urban infrastructure, dark niches, places where the countless surveillance cameras that control the public space cannot reach, but where passers-by were provoked by initially inconspicuous images. The figures show selected images of urban art in Lavapiés that were taken in 2011 and 2012 during and immediately after the onset of the 15M movement, which began on May 152011 in Spain and is known as one pioneer of the later worldwide Occupy movement.

Figure 1 shows an armed Spanish police officer as the shadow of the street post, indicating the state surveillance that has increased significantly in the neighborhood. The image is provocative because it has been fixed in front of a police training center. In Figure 2, the image of an African mother carrying her baby is integrated into the street furniture, demonstrating her belonging to the neighborhood. Figure 3 shows a sticker of the Three Magi being pursued by a helicopter-a strong image designed to raise sensitivity to the politics of social exclusion, racist identity controls, and Islamophobia ${ }^{16}$ in Spanish society, which includes significant numbers of Arabs and Muslims.

These examples of urban art in Madrid show that the city is serving as the organism, the holistic system within which the "new urbanism of the everyday" is emerging through "transitivity", "daily rhythms", and

${ }^{15}$ Characterized as one of the 20 most important global cities, Madrid is an important hub for the finance and logistics sectors and the third largest city in the EU, after London and Berlin, with over 3.3 million inhabitants in the city (and over 6.5 million in the metropolitan region) (Ayuntamiento de Madrid, 2012).

16 Especially after the bomb attacks in the central station of Atocha, Madrid, in 2005. 
"situated footprint effects" (see Amin \& Thrift, 2002, p. 7). Creative political acts, urban art, and strategies to inscribe the city with creative tactics and poetics are questioning dominant tenure and property rights and are producing new forms of urban belonging by associating spatial shapes with socio-spatial practices. They arise from a political landscape that has built on the

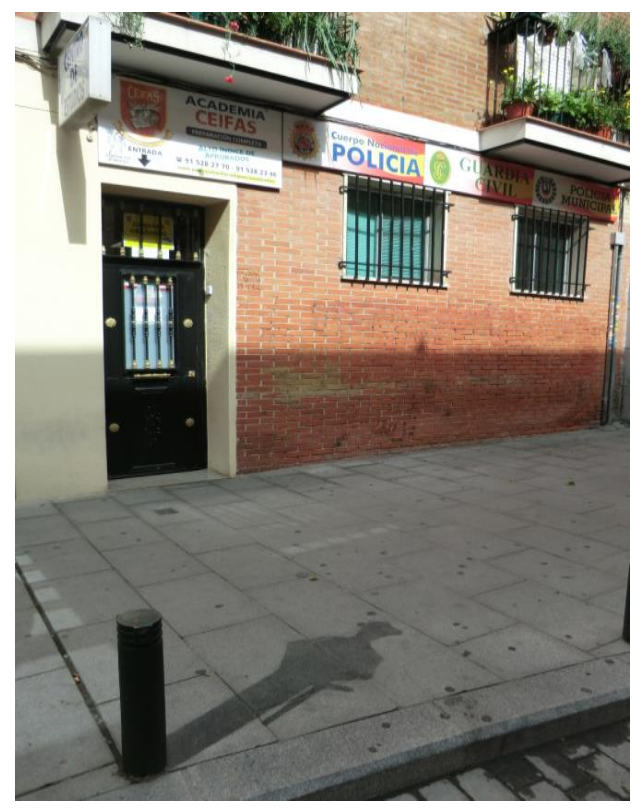

Figure 1. Doctor Foquet Street (Sebaly). potential of those who need to set up home in a situation of transitivity, under conditions of un-belonging and the lack of citizenship rights. However, creative activism in the face of neoliberal politics and revanchist urban governments is under increasing pressure to legitimize itself, which makes mechanisms of selfreflection more necessary than ever.

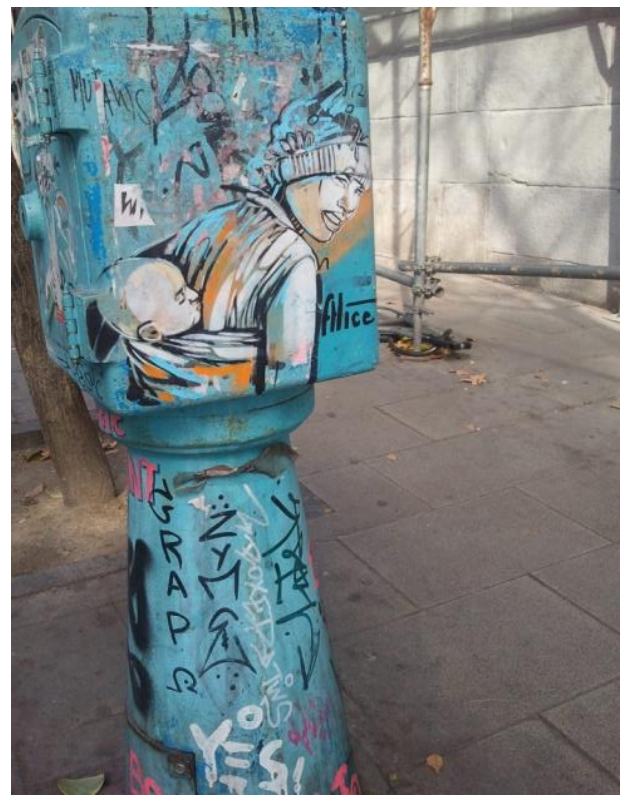

Figure 2. Embajadores Street (Youkhana).

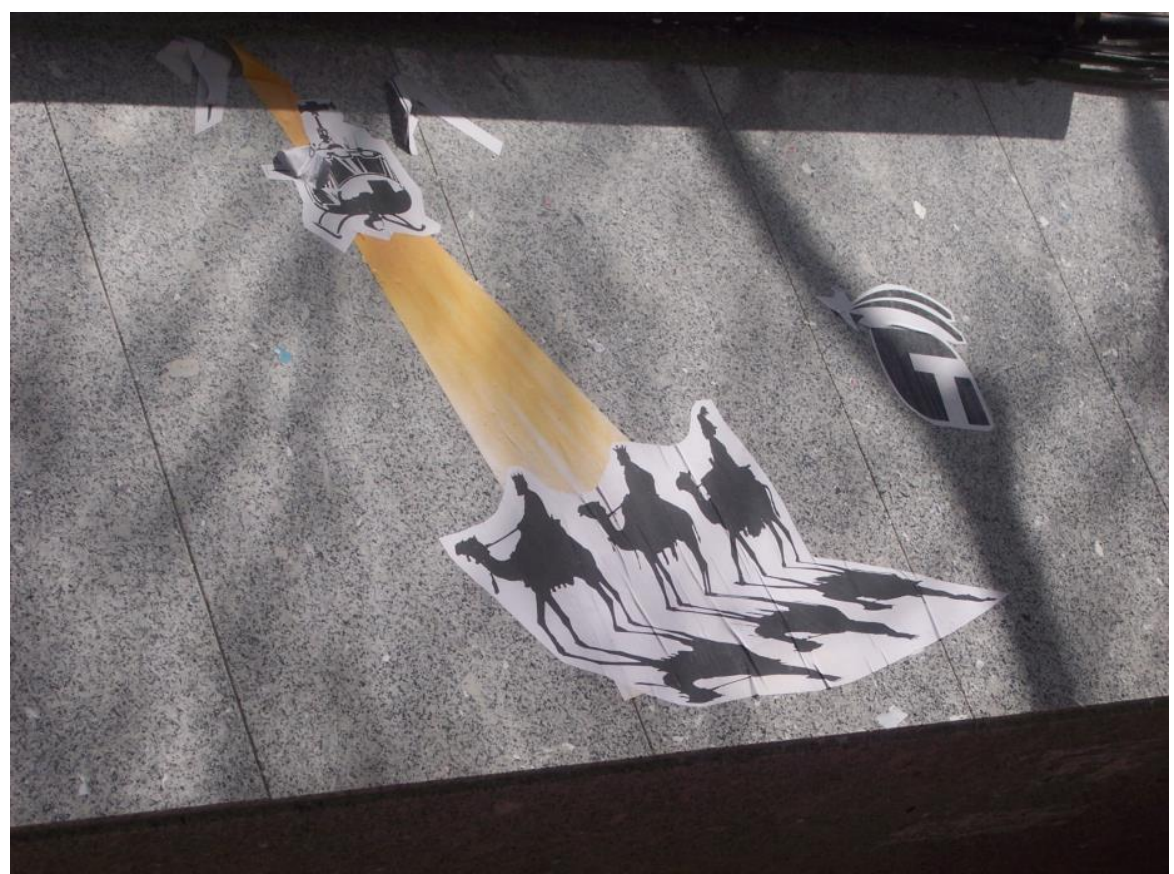

Figure 3. Political stencil in Argumosa Street (Youkhana).

\section{Conclusion}

The paper showed how groupist perspectives on the social interact with concepts of belonging and the related politics of belonging, through the example of the nation state and citizenship, which are still today the most important reference points for social and territorial demarcations and exclusion. Avoiding methodological nationalism, a concept of belonging was developed that includes space as an analytical category and that adopts a material-semiotic perspective on the study of social formation. With a new definition of belonging, 
the concept analytically integrates the material in three ways: through corporeal and embodied experiences and internalized biographies; through tenure relations, the allocation of resources, and the related enforcement strategies, technologies, infrastructures, and microphysics; and through objects and artefacts that serve as bearers of agency and represent signification procedures.

The selected case studies of the Virgin of Cisne and creative activism and urban art in Madrid showed under which conditions of social inequality and power asymmetries belonging is produced and (re)presented. The case studies do justice both to the bounded and naturalized notions of belonging and to the open and reflexive notions of belonging that are implied in different practices and projects of belonging. On the one hand, belonging is revealed as a bounded conception that relies on imposed collective identities that are reproduced in order to legitimize cultural hegemony and social and political domination while hampering emancipatory forces, as seen in the example of the Virgen del Cisne. On the other hand, it was shown that belonging increasingly derives from complex interconnections through mediating objects, including urban forms, infrastructures, and signs, as demonstrated by the uncommissioned and politically motivated urban art in Madrid. What Baumann (2000) calls the "central human experience" and the lived circulation of people, concepts, and objects, is most intensively felt in situations of migration. Our codes of the social become destabilized, which creates, according to Waldmann (2011, p. 159), a (new) social figure of a traveller, a nomad (cf., Papadopoulos \& Tsianos, 2007) who also enjoys the lack of rootedness while changing the conditions of her material existence in an ongoing process of becoming (Papadopoulos \& Tsianos, 2007, p. 223). Of course, the complex interconnections can also stabilize these codes by returning to primordial claims in precarious socio-economic conditions. The productions of belonging are then related to senses of un-belonging triggered by exclusionary migration politics, as has been experienced by migrants in Spain and Europe in recent years and diaspora communities in general.

This paper is not an attempt to deny trajectories, dependencies and inequalities that are located at the intersection of different social categories and contestations. Instead the paper offers some thoughts about how to shift studies of belonging from ideas of vertical, rooted, and path-dependent constructions to equally valid notions of a more open, grassy social landscape ${ }^{17}$

17 The images and distinction of "rooted" and "grassy" social relations, the binary opposition of vertical and horizontal social relations, is taken from the book "A thousand plateaus" by Deleuze and Guattari, who depicts Western binary thinking and related ideas about the social world and exposes their reductionism. with horizontal and situated relations, for example in public urban or virtual spaces, which also describe social reality. Approaching belonging from what is performed as belonging and how it is enacted in certain situations allow us to better understand which instruments are used in processes of "othering" (Spivak, 1985) or distancing, and by whom these processes are sustained. And it brings to prominence the question of when and under which conditions new belongings are produced. It unveils the politics and socio-economic settings that are connected to the multiple sources of social inequality and shows how they are translated into signification procedures, knowledge systems, ideologies and institutions that often serve to legitimize social and territorial exclusion and establish border regimes. It is all the more amazing how commonality and mutuality beyond a given national or ethnic position function successfully on the part of multi-national entrepreneurialism and the financial world, and, as Çağlar and Glick-Schiller (2011, p. 5) mention, how the neoliberal rescaling and restructuring have disrupted fixed notions of territoriality and bounded political units. Why then should migrants stick to their genealogies of belonging, the imagined roots, and related political boundaries, when they hamper both movement and processes of becoming, and thus also the human right to take responsibility for one's own life?

\section{Acknowledgements}

I like to thank my colleagues at the University of Bonn (ZEF, ILZ, Department for Ancient American Studies and Anthropology) and at the Research Network on Latin America for their ongoing scientific support und the fruitful discussions about the concept of belonging. I also want to express my thanks to the Federal Ministry of Research and Education (BMBF) for their generous financial support. Of course the paper would not have been realized without the countless interviewees in Spain, Madrid and Lavapiés.

\section{Conflict of Interests}

The author declares no conflict of interests.

\section{References}

Abarca Sanchís, F. J. (2015).Graffiti, street art and gentrification. In E. Youkhana \& L. Förster (Eds.), GraffiCity: Visual practices and contestation in urban space (pp. 221-234). Paderborn, Germany: Wilhelm Fink.

Abaza, M. (2015). Graffiti and the reshaping of the public space in Cairo. Tensions between political struggles and commercialization. In E. Youkhana \& L. Förster (Eds.), GraffiCity: Visual practices and contestation in urban space (pp. 267-294). Paderborn, 
Germany: Wilhelm Fink

Abler, R., Adams, J., \& Gould, P. (1971). Spatial organization. UK: Englewood Cliffs.

Alber, R. (1997). New York street reading-Die Stadt als Beschrifteter Raum. Dokumenation von Schriftzeichen und Schriftmedien im Strassenraum und Utntersuchung Ihrer Stadträumlichen Bedeutung am Beispiel New York. Tübingen, Germany: Dissertation Eberhard-Karls-Universität Tübingen.

Amin, A. (2008). Collective culture and urban public space. City: Analysis of Urban Trends, Culture, Theory, Policy, Action, 12(1), 5-25.

Amin, A., \& Thrift, N. (2002). Cities. Reimagining the urban. Cambridge, UK: Polity Press.

Albiez, S., Castro, N., Jüssen, L., \& Youkhana, E. (2011). Introduction. In S. Albiez, N. Castro, L. Jüssen, \& E. Youkhana (Ed.), Etnicidad, ciudadanía y pertenencia: Prácticas, teoría y dimensiones especiales (pp. 11-32). Frankfurt am Main, and Madrid: Iberoamericana, Vervuert.

Anderson, B. (1983). Imagined communities. Reflections on the origin and spread of nationalism. London, UK: Verso.

Althusser, L. (2010 [1971]). Ideologie und ideologische Staatsapparate. In F. O. Wolf (Ed.), Gesammelte Schriften (pp. 37-125). Hamburg, Germany: VSA Verlag.

Anthias, F. (2006). Belongings in a globalizing and unequal world: Rethinking translocations. In N. YuvalDavis, K. Kannabiran, \& U. Vieten (Eds.), The situated politics of belonging (pp. 365-388). London, UK: Thousand Oaks.

Anthias, F. (2008). Thinking through the lens of translocational positionality: An intersectionality frame for understanding identity and belonging. Translocations: Migration and Social Change, 4(1), 5-20.

Anthias, F. (2009). Intersectionality, belonging and translocal positionality: Thinking about transnational identities. In G. Rosenthal (Ed.), Ethnicity, belonging and biography: Ethnographical and biographical perspectives (pp. 229-249). Münster, Westfalen: Lit Verlag.

Antonsich, M. (2010). Searching for belonging-An analytical framework. Geography Compass, 4(6), 644-659.

Ayuntamiento de Madrid (2012). Madrid economy 2012. Economic observatory. Retrieved from http:// www.madrid.es/UnidadesDescentralizadas/UDCOb servEconomico/MadridEconomia/Ficheros/AF_MA DRID\%20ECONOMIA\%202012\%20INGLES_baja.pdf

Barth, F. (1969). Introduction. In F. Barth (Ed.), Ethnic groups and boundaries: The social organization of culture difference (pp. 9-38). London, UK: Universitets Forlaget, George Allen \& Unwin.

Baudrillard, J. (1978). Kool Killer-Oder der Aufstand der Zeichen. Berlin, Germany: Merve Verlag.

Baumann, Z. (2000). Liquid modernity. Cambridge, UK:
Polity Press.

Bell, C. (1997). Ritual. Perspectives and dimensions. Oxford: Oxford University Press.

Bell, V. (1999). Performativity and belonging: An introduction. Theory, Culture, Society, 16(2), 1-10.

Belina, B. (2013). Raum. Zu den Grundlagen eines historisch-geographisch Materialismus. Münster, Germany: Westfälisches Dampfboot.

Blasius, J., \& Friedrichs, J. (2008). Lifestyles in distressed neighborhoods. A test of Bourdieu's "taste of necessity" hypothesis. Poetics, 36, 24-44.

Bogner, A., \& Rosenthal, G. (2009). Introduction: Ethnicity, biography and options of belonging. In A. Bogner, \& G. Rosenthal (Eds.), Ethnicity, belonging and biography. Ethnographical and biographical perspectives (pp. 9-23). Münster, Germany; London, UK: Lit Verlag.

Bourdieu, P. (1992). Die verborgenen Mechanismen der Macht. Schriften zu Politik und Kultur I. Hamburg: VSA-Verlag.

Brubaker, R. (2009). Ethnicity, race, nationalism. Annual Review of Sociology, 35, 21-42.

Brubaker, R., \& Cooper, F. (2000). Beyond identity. Theory and Society, 29, 1-47.

Büschges, C., \& Pfaff-Czarnecka, J. (2007). Die Ethnisierung des Politischen. Frankfurt a.M., Germany: Campus Verlag.

Castells, M. (1996). The rise of the network society (3 vols.). The information age: Economy, society and culture I. Cambridge/ Oxford, UK: Blackwell.

Castells, M. (2002 [1997]). Das Informationszeitalter II. Die Macht der Identität. Opladen, Germany: Leske und Budrich.

Certeau, M. D. (1980). Kunst des Handelns. Berlin, Germany: Merve Verlag.

Clifford, J. (1992). Travelling cultures. In L. Grossberg (Ed.), Cultural studies (pp. 96-112). New York, USA: Routledge.

Conrad, C., \& Kocka, J. (2001). Staatsbürgerschaft in Europa: Historische Erfahrungen und aktuelle Debatten. Hamburg, Germany: Ed. Körber-Stiftung.

Cachón Rodríguez, L. (2009). La "España inmigrante": Marco discriminatorio, mercado de trabajo y políticas de integración. Barcelona: Anthropos.

Christensen, A.-D. (2009). Belonging and unbelonging from an intersectional perspective. Gender, Technology and Development, 13(1), 21-41.

Crowley, J. (1999). The politics of belonging: Some theoretical considerations. In A. Geddes, \& A. Farrel (Eds.), The politics of belonging: Migrants and minorities in contemporary Europe (pp. 15-41). Aldershot, UK: Ashgate.

Debord, G. (1957). Report on the construction of situations and on the international situationist tendency's conditions of organization and action. Bureau of Public Secrets. Retrieved from http://www.bop secrets.org 
Elwert, G. (1989). Nationalismus und Ethnizität: Über die Bildung von Wir-Gruppen (Occasional papers Nr. 22). Berlin, Germany: Verlag das Arab.

Favrot Peterson, J. (1992). The virgin of Guadalupe: Symbol of conquest or liberation. Art Journal, 51(4), 39-47.

Fortier, A.-M. (2000). Migrant belongings: Memory, space, identities. Oxford: Berg.

García, P. (2005). La inmigración: Un nuevo reto para la Iglesia católica española. Anuario Americanista Europeo, 3, 1-21.

Gabbert, W. (2006). Concepts of ethnicity. Latin American and Caribbean Ethnic Studies, 1(1), 85-103.

Gabbert, J. (2007). Street Art-Kommunikationsstrategie von Off-Kultur im Urbanen Raum. Master thesis at the Freie Universität Berlin, Germany. Retrieved from http://rosalux.de/fileadmin/ls_sh/dokumente/ veranstaltungen_2010/reclaimStreet_masterarbeit gabbert.pdf

Gell, A. (1998). Art and agency. An anthropological theory. Oxford, United Kingdom: University Press.

Gellner, E. (2006). Nations and nationalism (New perspectives on the past). Oxford, United Kingdom: Blackwell Publishers.

Geschiere, P. (2011). Autochthony, citizenship and exclusion. New patterns in the politics of belonging in Africa and Europe. In S. Albiez, N. Castro, L. Jüssen, \& E. Youkhana (Eds.), Etnicidad, ciudadanía y pertenencia: Práticas, teoría y dimensiones especiales (pp. 175-198). Frankfurt am Main, Germany/ Madrid, Spain: Iberoamericana, Vervuert.

Gilroy, P. (1987). There ain't no black in the Union Jack: The cultural politics of race and nation. London, UK: Hutchinson.

Çağlar, A., \& Glick-Schiller, N. (2011). Introduction: Migrants and cities. In N. Glick-Schiller \& A. Çağlar, (Eds.), Locating migration. Rescaling cities and migrants (pp. 1-19). New York, USA: Cornell University Press.

Hall, S. (1985). Signification, representation and ideology. Althusser and the post-structuralist debate. Critical Studies in Mass Communication, 2(2), 91-114.

Hamel, P., Lustiger-Thaler, H., \& Maheu, L. (2000). Late modern institutions and collective action. In $\mathrm{S}$. Quash \& A. Sales (Eds.), The international handbook of sociology (pp. 255-270). London, UK: SAGE Publications.

Hanauer, D. I. (2011). The discursive construction of the separation wall at Abu Dis. Journal of Language and Politics, 10, 301-321.

Haynes, J. (2009). Introduction. In J. Haynes (Ed.), Routledge handbook of religion and politics (pp. 17). Ney York, USA: Routledge.

Heinrich, M. (2013). Graffiti. Unpublished Term Paper at the Department for Anthropology at the University of Bonn, Germany.

Hobsbawm, E., \& Ranger, T. (1983). The invention of tra- dition. Cambridge, UK: Cambridge University Press.

Isin, E., \& Turner, B. (2002). Citizenship studies: An introduction. Handbook of citizenship studies (pp. 110). Los Angeles, USA: Sage.

Isin, E. (2009). Citizenship in flux: The figure of the activist citizen. Subjectivity, 29(1), 367-388.

Isin, E., \& Turner, B. (2007). Investigating citizenship: An agenda for citizenship studies. Citizenship Studies, 11(1), 5-17.

Itçaina, X. (2006). The Roman Catholic Church and the immigration issue. The relative secularization of political life in Spain. American Behavioral Scientist, 11(49), 1471-1488.

Janoschka, M., \& Sequera, J. (2011). Zur symbolischen Rückeroberung und Politisierung des öffentlichen Raums. PROKLA Zeitschrift für kritische Sozialwissenschaft, 166(42), 163-172.

Jansen, M. M., \& Keval, S. (2003). Religion und Migration. Die Bedeutung von Glauben in der Migration. POLIS 38. Wiesbaden, Germany: Hessische Landeszentrale für politische Bildung.

Joas, H. (1994). Situation-Corporeality-Sociality. The fundamentals of a theory of creativity of action. In H. Joas (Ed.), The creativity of action. (pp. 145-195). Chicago: University of Chicago Press.

Joppke, C. (2010). Citizenship and immigration. Cambridge, UK: Polity.

Kymlicka, W. (1995). Multicultural citizenship: A liberal theory of minority rights. Oxford, UK: Clarendon; New York, USA: Oxford University Press.

Latour, B. (2005). Reassembling the social. An introduction to actor-network-theory. New York, USA, Oxford, UK: University Press.

Law, J. (2011). Akteur-Netzwerk-Theorie und materielle Semiotik. In T. Conradi, H. Derwanz, \& F. Muhle (Eds.), Strukturentstehung durch VerflechtungAkteur-Netzwerk-Theorie(n) und Automatismen (pp. 21-48). München, Germany: Wilhelm Fink Verlag.

Lefebvre, H. (2006). Die Produktion des Raums. In J. Dünne \& S. Günzel (Eds.), Raumtheorie. Grundlagentexte aus Philosophie und Kulturwissenschaften (pp. 330-342). Frankfurt am Main, Germany: Suhrkamp Taschenbuch Verlag.

Leitner, H., Sheppard, E., \& Sziarto, K. (2008). The spatialities of contentious politics. Transactions of the Institute of British Geographers, 33(2), 157-172.

Lentz, C. (2006). Land rights and the politics of belonging in Africa: An introduction. In R. Cuba \& C. Lentz (Eds.), Land and the politics of belonging in West Africa (pp. 1-35). Leiden, Netherlands, Boston, USA: Brill.

Lepovsky, J., \& Frazer, J. (2003). Building community citizens: Claiming the right to place-making in the city. Urban Studies, 40(1), 127-142.

Levitt, P. (2004). Redefining the boundaries of belonging: The institutional character of transnational religious life. Sociology of Religion, 65(1), 1-18. 
López, A. (1998). El arte de la calle. Reis, 84, 173-194.

Magerski, C. (2005). Die Wirkmacht des Symbolischen. Von Cassierers Philosophie der symbolischen Formen zu Bourdieus Soziologie der Symbolischen Formen. Zeitschrift für Soziologie, 34(2), 112-127.

Marshall, T. (1950). Citizenship and social class and other essays. Cambridge, UK: CUP.

Massey, D. (2005). For Space. London, UK: Sage.

Maj, J. (2013). The significance of intersectionality for feminist political theory. Retrieved from http://www.e-ir.info/2013/11/01/the-significanceof-intersectionality-for-feminist-political-theory

McCall, L. (2005). The complexity of intersectionality. Journal of women in Culture and Society, 30(3), 1771-1800.

Nabham-Warren, K. (2005). Mary. In E. D. Aponte \& M. A. de la Torre (Eds.), Handbook of Latina/o theologies (pp. 243-254). St. Louis, USA: Charlize Press.

Nakano-Glenn, E. (2011). Intersections, articulations and assemblages. Unpublished paper presented at the $2^{\text {nd }}$ International Symposium of the Research Network for Latin America, 12-14 September 2011, Cologne, Germnay.

Ong, A. (1999). Flexible citizenship: The cultural logics of transnationality. Durham, UK: Duke University Press.

Oxford Dictionary of English Etymology (1989). (2nd Edition). Oxford, New York: Oxford University Press.

Papadopoulos, D., \& Tsianos, V. (2007). The autonomy of migration: The animals of the undocumented mobility. In A. Hickey-Moody \& P. Malins (Eds.), Deleuzian encounters: Studies in contemporary social issues (pp. 223-235). London, New York: Palgrave Macmillan.

Pedone, C. (2003). Tú siempre jalas a los tuyos. Cadenas y redes migratorias de las familias ecuatorianas hacia España. Barcelona, Spain: Universitat Autònoma de Barcelona.

Pfaff-Czarnecka, J. (2011). From "identity" to "belonging" in social research: Plurality, social boundaries, and the politics of the self. In S. Albiez, N. Castro, L. Jüssen, E. Youkhana (Eds.), Etnicidad, ciudadanía y pertenencia: Práticas, teoría y dimensiones especiales (pp. 197-218). Frankfurt am Main, Germany, and Madrid, Spain: Iberoamericana, Vervuert.

Pfaff-Czarnecka, J. (2013). Multiple belonging and the challenges to biographic navigation (MMG Working Paper 13-15). University of Bielefeld, Germany. Retrieved from http://www.isa-sociology.org/publ/Esymposium/E-symposium-vol-3-1-2013/EBulPfaffCzarnecka-Mar2013.pdf

Pierce, J., Martin, D., \& Murphy, J. (2011). Relational place-making: The networked politics of place. Transactions of the Institute of British Geographers, 36(1), 54-70.

Rosaldo, R. (1989). Culture \& truth: The remaking of social analysis. Boston, USA: Beacon Press.
Savage, M., Bagnall, G., \& Longhurst, B. (2005). Globalization and belonging. London, UK: Thousand Oaks, Calif: Sage.

Scheibelhofer, E. (2011). Raumsensible Migrationsforschung. Methodische Überlegungen und empirische Relevanz für die Migrationssoziologie. Wiesbaden, Germany: VS-Verlag für Sozialwissenschaften.

Schmid, C. (2005). Stadt, Raum und Gesellschaft: Henri Lefebvre und die Theorie der Produktion des Raumes. München, Germany: Franz Steine Verlag.

Schmid, C. (2008). Henri Lefebvre's theory of the production of space: Towards a three-dimensional dialectic. In K. Goonewardena, S. Kipfer, R. Milgrom, \& C. Schmid (Eds.), Space, difference, everyday life: Reading Henri Lefebvre (pp. 27-45). New York, USA: Routledge.

Social Issues Research Centre. (2008). Belonging. Retrieved from http://www.sirc.org/publik/belonging. pdf

Spivak, G. C. (1996). Subaltern studies: Deconstructing historiography. In D. Landry \& G. MacLean (Eds.), The Spivak reader (pp. 203-236). London, UK: Routledge.

Ströbele-Gregor, J. (2010). When difference matters: The construction of identity, gender, "otherness" and citizenship in indigenous discourses in Andean societies. Bonn, Germany: University of Bonn.

Urry, J. (2000). Mobile sociology. The British Journal of Sociology, 61, 347-366.

Waldmann, G. (2011). Nómades y migrantes. Resignificando hogares y pertenencias. In S. Vedia (Ed.), Acercamientos a la cuestión migratoria. El conglomerado migratorio (pp. 157-168). Mexico City: Universidad Nacional Autónoma de México.

Waldner, L. K., \& Dobratz, B. A. (2013). Graffiti as a form of contentious political participation. Sociology Compass, 7(5), 377-389.

Walters, W. (2013). The flight of the deported: Deportation, aviation and politics. Paper presented at The Margins of Citizenship: "Deportability", Illegality and Statelessness, Villa Vigoni, Menaggio, Italy. Retrieved from https://www.academia.edu/5087529/ Flight_of_the_Deported_Deportation_Aviation_and _Politics

Wimmer, A., \& Glick-Schiller, N. (2006). Methodological nationalism and beyond: Nation-state building, migration and the social sciences. Global Networks, 2(4), 301-334.

Wimmer, A. (2009). Herder's heritage and the boundary-making approach: Studying ethnicity in immigrant societies. Sociological Theory, 27(3), 244-270.

Windzio, M. (2010). Warum Begehen Jugendliche Graffiti-Delikte? Kriminologische und Stadtsoziologische Perspektiven. In A. Klee (Ed.), Politische Kommunikation im Städtischen Raum am Beispiel Graffiti (pp. 67-90). Wiesbaden, Germany: VS Verlag für 
Sozialwissenschaften.

Yashar, D. (2005). Contesting citizenship in Latin America. New York: Cambridge University Press.

Youkhana, E., \& Sebaly, C. (2014). GraffiCity-Kreativer Protest, belonging und citizenship im Madrider Stadtteil Lavapiés. Suburban, 2(1), 49-70. Retrieved from http://www.zeitschrift-suburban.de/sys/index. php/suburban/article/view/107/html_5

Youkhana, E. (2014a). Creative activism and art against urban renaissance and social exclusion-Space sensitive approaches to the study on collective action and belonging. Sociology Compass, 8(2), 172-186.

Youkhana, E. (2014b). Die Macht der Dinge in transna- tionalen religiösen Räumen-Die Virgen del Cisne in Madrid. Peripherie, 134/135, 149-174.

Yuval-Davis, N. (1997). Gender and nation. London: Sage Publications.

Yuval-Davis, N. (2006). Belonging and the politics of belonging. Patterns of Prejudice, 40(3), 197-214.

Yuval-Davis, N. (2011). The politics of belongingIntersectional contestations. London, Thousand Oaks, New Delhi, Singapore: SAGE.

Zires, M. (1994). Los mitos de la Virgen de Guadalupe. Su proceso de construcción y reinterpretación en el México pasado y contemporáneo. Mexican Studies, 2(10), 281-313.

\section{About the Author}

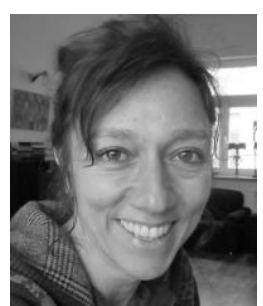

\section{Eva Youkhana}

Eva Youkhana holds a PhD in Sociology and a Masters in Social Anthropology. During her academic career she was involved in several interdisciplinary environmental projects, projects on migration and urban studies focusing on Latin America, West Africa and Europe. After working as a Researcher at the Center for Development Research (ZEF) in Bonn, she joined the Research Network on Latin America: Ethnicity, Citizenship, Belonging and the Interdisciplinary Latin America Center (ILZ) as a PostDoc in 2010. Her current research interests are connected to space and material semiotic perspectives on migration, collective action and belonging. 